\title{
貧困と基底的承認
}

\section{Poverty and Elementary Recognition}

\author{
早川洋行
}

Hiroyuki HAYAKAWA

2011 年 9 月 8 日、新潟大学で行われた第 29 回大会シンポジウムは、「都市社会学は『貧 困』にどう向き合うか」をテーマにして開催された。これは前年のテーマ部会「大都市に おける貧困の現在」を引き継いだものである。この特集は、シンポジウムで報告していた だいた三名の方々にご寄稿を願つた。

西澤論文は、貧困の特殊現代的な有り様を論じている。今日、貧者は「個人化された存 在」となっている。かつて、集団として存在した貧困層は、スラムや貧民窟や下町やムラ において、コミュニティを形成していた。そこには他者による承認があったのである。と ころが現代の貧者は、そうした集団性を担保する場所をはく奪されている。西澤によれ ば、場所とは「他者との空間的な接触媒体」である。そうであるからこそ、これまで貧者 の問題と都市や地域の問題は接点をもつことができた。今や状況は一変した。現代の貧者 は、ケータイをもって散在している。それを「場所からの解放」と呼べなくもないが、そ の意味するところは、上層と下層では大きく異なる。上層は、旅行者として流動し、選び 直された定住者として定住する。一方、下層は、放浪者として流動し、「しゃがみ込む 人々」として定住するのである。貧者はただ行き場を失つた存在でしかない。こうした現 実を前にして、都市社会学はいかにして貧困を語りうるのか。西澤は、「定住ではなく流 動をこそ常態として見る見方」を取り入れること、そして「暗い海を共通了解として、ど こか儚い世界を作り上げながら生存・存在しようとする人々を掬い上げようとすることに よって」であると結論付けている。

松宮論文は、地域コミュニティの弱体化が関係性の貧困を招き、その極限的な形態とし て高齢者の「孤独死」「孤立死」があるとして、そこから単純に地域コミュニティの強化 を導く思考に疑問を提示する。そして松宮は、「孤独死」「孤立死」の実証的な調査から、 具体的データをあげて、この認識の誤りを指摘するとともに、「孤独死」「孤立死」の予防 策を考察している。彼によれば、そもそも「孤独死」「孤立死」が何故問題なのか、とい う点は明確にされていない。にもかかわらず、公的サービスよりもコミュニティ活性化が 期待されている。そして一方で高齢者の経済的貧困と階層問題が等閑視されてきた。調查 
結果は、貧困が高齢者の「孤独死」「孤立死」のリスクを高めること、「孤独死」「孤立死」 した人が完全に孤立していたということは少ないこと、援助拒否や進んで孤立を選択する 人々がいることなどを明らかにしている。こうした事実を踏まえるならば、単純にコミュ ニティを強化して「孤独死」「孤立死」を防ごうとするのは誤りであり、むしろ「行政の 責任の明確化と選択可能なネットワークの構築」こそが、望まれる。

文論文は、貧困問題にジェンダーの視点からアプローチしている。1990年代中ごろか らの一連の規制緩和によって、労㗢の多様性は急速に拡大した。それは、正規労働と非正 規労働をナショナリティとジェンダーという二つの指標によってセグメントすることでも あった。これによって、「多くの女性労㗢者は、『やりがいのある仕事』での自己実現では なく、そのサービス労働者としての資質を評価してもらうことで、『やりがいのない仕事』 (「キツイ仕事」「低賃金の仕事」) での自己承認をめざす状況」に置かれるようになったと 言う。文は、その実態を温泉リゾート地における女性労働者の歴史的変遷を事例にして説 明している。彼女によれば、1970年代から旅館やホテルは「不安定就労・居住不安定層」 としての女性労働者の雇用の場であった。「住み込々」の仲居職の求人が、女性週刊誌を 媒介にしてなされていたのである。ところが、90年代に入ると業務の外注化が進むととも に、旅館ホテル業に特化した人材派遣・職業紹介所が栄えるようになる。そして 2000 年 代以降は、「近距離出稼ぎ現象」や若年フリーターの増加が見られると言う。文は、女性 労働者にとって職業労働への参加は、家族の呪縛から解放され社会の呪縛にからめ捕られ るものだつたが、いまや呪縛の在り方が多様化し、諸個人を社会につなぎとめている場所 の差異が顕著になってきていると論じている。

さて、三つの論文は、貧困という統一テーマをめぐって、空間、高齢者、女性労働者と のかかわりから見えてくる問題を論じている。其々は極めて個性的であるが、それらには 通底するものがあるように思われる。

第一は、もはや共同体的秩序に期待することはできないという認識である。都市に出稼 ぎにきた労働者には帰るべきホームがあり、滞留する貧困層にも境遇を共有する者たちが 作る疑似的ホームがあった。しかし、ここバラバラに生きる現代の貧者にはそうしたもの はない。高齢者にとって地域共同体は自分を見守ってくれるものではなく、また高齢者自 身それを期待してもいない。女性労働者にとって、職場も家庭も、もはや安住地とはいえ ない。

第二は、共同体的秩序から零れ落ちる人たちを救うべき国家的秩序の機能不全である。 1990 年代以降の新自由主義政策は、国家としてのセーフティネットを弱体化させた。生活 保護を受ける人々の数は増加しており、中高年の問題であった失業問題は、若年層の就職 難の問題に波及している。ところが、政府はこうした状況に有効な改善策を講じることが できないまま、コミュニティや諸個人の自己努力に任せきりの状態が続いている。こうし たことの結果のひとつとして、「孤独死」「孤立死」と温泉リゾート地における就労形態の 
変化もあるのである。

問われていることは、もはや明確ではなかろうか。共同体的秩序が崩壊し、国家的秩序 があてにならない。そのいずれでもない第三の道しか、われわれには残されていない。

筆者は、共同体的秩序と国家的秩序の中間にある社会的秩序を機能強化することによつ てしか、この難局を乗り切ることはできないのではないかと考える。西澤が「どこか儚い 世界を作り上げながら生存・存在しようとする人々を掬い上げようとすること」といい、 松宮が「行政の責任の明確化と選択可能なネットワークの構築」と述べたことは、まさに それではなかったのか。

この点でA.ホネットが述べている「基底的承認」という考えは、極めて示唆的であ る。ホネットは「人間の世界に対する関係において承認（Anerkennen）がつねに認識 (Erkennen) に先行し、『物象化』という概念は、こうした優先秩序に対する侵犯として 理解されるべきだ」と述べている1)。近代社会は、まさにこれを逆転させ認識後の承認を 一般化させた。認識し承認したものしか中に入れないというゲーテッド・コミュニティ は、まさにその典型例である。しかし、それは人間を物象化するものにほかならない。

ホームレスであれ、高齢者であれ、女性労働者であれ、彼らは人間である以上、まず承 認されなければならない。どれほど困窮しているのか、介護認定がどのレベルであるか、 どのような家庭的事情を抱えているかは二の次である。こうした発想は、最近注目される ようになつたベーシック・インカム導入をめぐる議論にもつながるものだろう。

じつは私たちは、国民的な規模で、基底的承認が発動した経験をすでにもつている。東 日本大震災（3.11）は、まさに地域共同体を崩壊させ、国家による支援もほとんどあてに できない状況を作り出した。その時、無数のボランティア、そしてボランティアと言うよ りも、むしろ「疑似的な隣人」たちが、被災者に温かい手を差し伸べたことは、まだ記憶 に新しい。

筆者には、今日の貧困問題は、大震災後の「災害ユートピア」において可能であったこ とが、平時においても可能であるか、という問いを突き付けているように思われる。

注

1) Honneth, A., Nachbetrachung zu Verdinglichung, (出口剛司・宮本真也訳「『物象化』追考」) 『現代社会学理論研究』第 5 号、2011年、p.45. 